\title{
Inability to regain normal body mass despite extensive refuelling in great reed warblers following the trans-Sahara crossing during spring migration
}

\author{
Thord Fransson, Måns Karlsson, Cecilia Kullberg, Robert Stach and Christos Barboutis
}

T. Fransson (thord.fransson@nrm.se), Dept of Environmental Research and Monitoring, Swedish Museum of Natural History, Stockholm, Sweden. - M. Karlsson, Dept of Mathematics, Stockholm Univ., Stockholm, Sweden. - C. Kullberg and R. Stach, Dept of Zoology, Stockholm Univ., Stockholm, Sweden. - C. Barboutis, Antikythira Bird Observatory, Hellenic Ornithological Society/Birdlife Greece, Athens, Greece, and Natural History Museum of Crete, Univ. of Crete, Heraklion, Crete, Greece.

\begin{abstract}
Migratory birds wintering in Africa face the challenge of passing the Sahara desert with few opportunities to forage. During spring migration birds thus arrive in the Mediterranean area with very low energy reserves after crossing the desert. Since early arrival to the breeding grounds often is of importance to maximize reproductive success, finding stopover sites with good refuelling possibilities after the Saharan passage is of utmost importance. Here we report on extensive fuelling in the great reed warbler Acrocephalus arundinaceus on the south coast of Crete in spring, the first land that they encounter after crossing the Sahara desert and the Mediterranean Sea in this area. Birds were studied at a river mouth and due to an exceptional high recapture rate ( 45 and $51 \%$ in two successive years), we were able to get information about stopover behaviour in 56 individual great reed warblers during two spring seasons. The large proportion of trapped great reed warbler compared to other species and the large number of recaptures suggest that great reed warblers actively choose this area for stopover. They stayed on average 3-4 d, increased on average about $3.5 \mathrm{~g}$ in body mass and the average rate of body mass increase was $4.8 \%$ of lean body mass $\mathrm{d}^{-1}$. Wing length affected the rate of increase and indicated that females have a slower increase than males. The results found show that great reed warblers at this site regularly deposit larger fuel loads than needed for one continued flight stage. The low body mass found in great reed warblers (also in birds with high fat scores) is a strong indication that birds staging at Anapodaris still had not been able to rebuild their structural tissue after the strenuous Sahara crossing, suggesting that rebuilding structural tissue may take longer time than previously thought.
\end{abstract}

The Palearctic-African migration system involves crossing an extensive ecological barrier, the Sahara desert (Moreau 1972). The number of passerine and near-passerine birds involved in autumn migration has been estimated to be 2.1 billion (Hahn et al. 2009). The distance of inhospitable terrain is larger in spring than in autumn due to the annual movement of the equatorial Intertropical Convergence Zone (ITCZ) which results in dry conditions in the southern edge of Sahara during the Northern Hemisphere winter and spring (Zwarts et al. 2009). The distances to cover in the eastern part of Sahara, with few or no opportunities to refuel, can reach up to $2800 \mathrm{~km}$ for some species since birds also have to cross the Mediterranean Sea before reaching benign areas (Barboutis et al. 2011a). It is well known that birds substantially increase their fuel stores, mainly subcutaneous fat, close to the desert crossing (cf. Fry et al. 1970, Finlayson 1981, Jenni and Jenni-Eiermann 1998). In autumn, garden warblers Sylvia borin on Crete have been shown to fuel for about two weeks and depart across the Mediterranean Sea with fuel loads close to $100 \%$ of lean body mass (Fransson et al. 2008, Barboutis et al. 2014).
Although birds actively chose flight altitudes with favourable wind assistance to minimize energy expenditure over the desert (Schmaljohann et al. 2009) the large amount of fuel accumulated before taking off may still be crucial for successfully reaching the opposite side of the desert (Barboutis et al. 2011a). This is evident from the very low body masses of captured birds with depleted fuel stores that have been reported from several sites in north Africa and along the Mediterranean coast in spring (Flint and Stewart 1983, Spina et al. 1993, Waldenström et al. 2004, Barboutis et al. 2011b, Gargallo et al. 2011). After the desert crossing birds may need time to rebuild not only severely reduced fat stores, but also muscle tissue, particularly the breast and leg muscles, as well as internal organs that have been reduced and used as fuel during the crossing (Bauchinger et al. 2005).

Optimal migration theory state that migratory birds may choose between minimizing the overall time on migration, energy expenditure or predation risk (Alerstam and Lindström 1990). It is commonly assumed that time minimization is the main strategy within bird migration, 
but minimization of energy cost and predation risk may also be involved and the outcome can, depending on situation, be a balance between all three (Hedenström 2008). In spring, when reaching the breeding grounds early can be of prime importance to secure a high quality territory, a timeminimization strategy might be expected (Hasselquist 1998, Kokko 1999, Newton 2008). In line with this it has also been shown that the total duration of migration is shorter in spring than in autumn for many species (Fransson 1995, Tøttrup et al. 2012, Nilsson et al. 2013) including our study species, the great reed warbler Acrocephalus arundinaceus (Lemke et al. 2013). The difference in speed between the seasons can to a large extent be explained by a reduction in the time birds spend at stopovers in spring (Nilsson et al. 2013). Thus, information about spatio-temporal variation in stopover duration and body mass accumulation is crucial in order to understand the organization of the migratory journey in birds (Alerstam and Lindström 1990), but data on fuelling behaviour directly after the Sahara crossing is relatively scarce (but see Lavee et al. 1991, Gargallo et al. 2011, Arizaga et al. 2013).

This study focuses on the spring stopover behaviour, in particular refuelling rate and stopover duration, of the great reed warbler at a site in Greece, the Anapodaris river mouth in southern Crete. The location of Crete, in the middle of the Mediterranean Sea, makes it the first major land mass with benign feeding opportunities that birds following the eastern migration route reach. It is therefore an ideal site to study stopover behaviour in relation to the desert crossing in spring (Fig. 1). The nominate sub-species of great reed warbler has a breeding area ranging from the Iberian peninsula and France in the west, to southern Scandinavia in the north and eastward to the Caspian Sea, and the wintering area is situated in Africa south of the Sahara, from west Africa to South Africa (Cramp 1992). It is a common and widespread breeding bird in Greece (Handrinos and Akriotis 1997), but it has never been found breeding at Anapodaris river mouth (M. Dretakis pers. comm.). Due to an extremely high recapture rate of individual birds at the river mouth we are able to reveal new insight into the stopover strategies of the great reed warbler just after crossing an ecological barrier, the Sahara desert.

\section{Material and methods}

Daily bird ringing was carried out at Anapodaris river mouth in southern Crete $\left(34.59^{\circ} \mathrm{N}, 25.20^{\circ} \mathrm{E}\right)$ between 10 April and 7 May 2015 and between 12 April and 10 May 2016. Ringing was conducted from dawn until 13:00. Trapped birds were weighed to the nearest $0.1 \mathrm{~g}$ and maximum wing length (Svensson 1992) was recorded as a measurement of size. It is not possible to age or sex great reed warblers with certainty in spring, although males are on average larger in size than females (Svensson 1992). Visible subcutaneous fat stores were estimated according to a scale (0-6) based on Pettersson and Hasselquist (1985) and the size of the breast muscle was scored (0-3) following the 'Manual of field methods' (Bairlein 1995). All birds recaptured during days following ringing were registered, weighed and scored for fat and muscle. The study area at Anapodaris consists of reed beds $(<1 \mathrm{ha})$ at a river mouth and nearby scrubland and olive groves close to the coastline. Mist nets $(16 \mathrm{~mm}$ mesh size) were placed both in the reeds and in the surrounding area and consisted of four $12 \mathrm{~m}$ nets and eleven $9 \mathrm{~m}$ nets in 2015 and five $12 \mathrm{~m}$ nets and twelve $9 \mathrm{~m}$ nets in 2016. The total number of migrants ringed during the period was 212 in 2015 and 247 in 2016, of which 56 and 60 were great reed warblers, respectively. One bird in 2015 had no information about wing length and has thus been excluded in some of the analyses.

The minimum stopover period was calculated as the number of days from ringing until the last recapture. Thus, a bird trapped only once has a minimum stopover period of $0 \mathrm{~d}$, and a bird that was trapped two days in a row (but not more) has $1 \mathrm{~d}$, etc. The fuel deposition rate $\left(\mathrm{g} \mathrm{d}^{-1}\right)$ was calculated as the body mass increase from the first to the last trapping day, divided by the number of days between the first and last trapping. We also calculated a relative body mass increase, as the fuel deposition rate divided by the size-specific lean body mass (RMI, g LBM-1 $\mathrm{d}^{-1}$ ). A method for estimation of size-specific lean body mass (LBM) from wing length of great reed warblers was derived from birds with no visible fat ringed at Antikythira during spring migration 2007-2015 $\left(\mathrm{LBM}=-0.0415+0.237 \times\right.$ wing length, $\mathrm{r}^{2}=0.29, \mathrm{n}=37$, $\mathrm{p}<0.001$ ), representing birds in a similar stage of migration
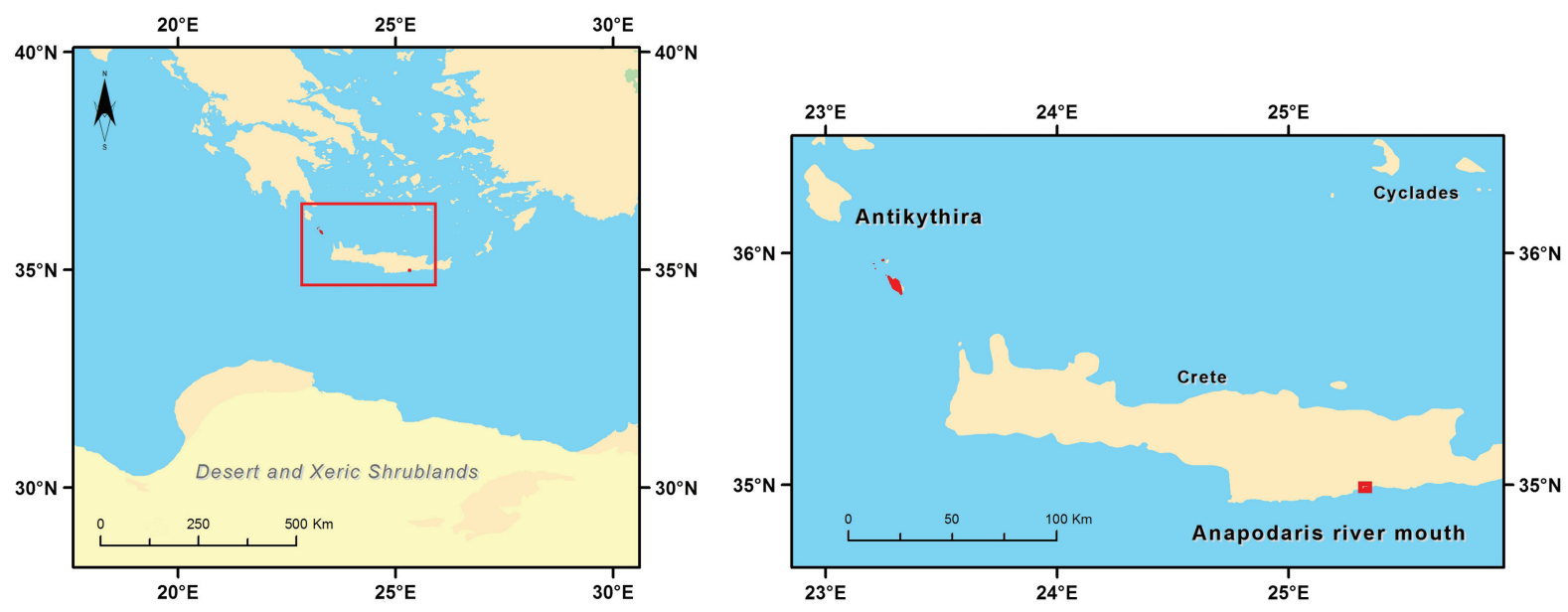

Figure 1. Maps showing the location of the study site at Anapodaris river mouth in southern Crete and the location of Antikythira Bird Observatory. 
Table 1. Descriptive statistics for great reed warblers ringed and recaptured at Anapodaris river mouth, Crete, in 2015 (10 April-7 May) and in 2016 (12 April-10 May).

\begin{tabular}{|c|c|c|c|c|c|c|}
\hline \multirow[b]{2}{*}{ Variable } & \multicolumn{3}{|c|}{2015} & \multicolumn{3}{|c|}{2016} \\
\hline & Average $\pm \mathrm{SD}$ & Range & $\mathrm{n}$ & Average $\pm \mathrm{SD}$ & Range & $\mathrm{n}$ \\
\hline Wing length & $97.3 \pm 3.2 \mathrm{~mm}$ & 91-106 & 55 & $96.9 \pm 2.8 \mathrm{~mm}$ & 89-102 & 60 \\
\hline Body mass at ringing & $27.0 \pm 3.8 \mathrm{~g}$ & $20.8-36.0$ & 56 & $27.6 \pm 3.8 \mathrm{~g}$ & $21.9-39.8$ & 60 \\
\hline Body mass in birds recaptured & $25.2 \pm 2.9 \mathrm{~g}$ & $20.8-32.2$ & 25 & $26.4 \pm 3.0 \mathrm{~g}$ & $21.9-32.9$ & 31 \\
\hline Body mass in birds not recaptured & $28.4 \pm 3.9 \mathrm{~g}$ & $22.0-36.0$ & 31 & $28.8 \pm 4.4 \mathrm{~g}$ & $22.1-39.8$ & 29 \\
\hline Body mass at last recapture & $28.8 \pm 3.6 \mathrm{~g}$ & $22.4-34.7$ & 25 & $29.7 \pm 3.8 \mathrm{~g}$ & $24.0-38.7$ & 31 \\
\hline Body mass increase & $3.6 \pm 2.8 \mathrm{~g}$ & $0.2-11.4$ & 25 & $3.3 \pm 2.7 \mathrm{~g}$ & $-1.2-10.5$ & 25 \\
\hline Fuel deposition rate & $1.0 \pm 0.4 \mathrm{~g} \mathrm{~d}^{-1}$ & $0.2-1.6$ & 25 & $1.2 \pm 0.8 \mathrm{~g} \mathrm{~d}^{-1}$ & $-0.9-3.0$ & 25 \\
\hline Minimum stopover time & $3.8 \pm 3.1 \mathrm{~d}$ & $1-13$ & 25 & $2.9 \pm 2.0 \mathrm{~d}$ & $1-10$ & 25 \\
\hline Fat score at ringing & $2.6 \pm 1.7$ & $0-6$ & 55 & $3.1 \pm 1.6$ & $0-6$ & 60 \\
\hline Muscle score at ringing & $1.5 \pm 0.6$ & $0-2$ & 55 & $1.6 \pm 0.8$ & $0-3$ & 60 \\
\hline
\end{tabular}

as birds at Anapodaris river mouth (Antikythira Bird Observatory unpubl., Fig. 1). Average values are presented \pm SD.

The RMI was modeled using a linear model with multiple predictors, exploiting that the response data at least is approximately normally distributed. We chose to regard a predictor as significantly influential on the response when its coefficient estimate had a p-value of 0.05 or less. We forced the intercept term to zero, since the RMI at ringing, the way we calculate it, has to be zero. The initial set of predictors was comprised by variables that we deemed could possibly affect the RMI and this set showed some signs of multicollinearity, i.e. there were some correlations among the predictors, but the level is not likely to affect our general conclusion (cf. Sundberg 2002). The initial model, based on the whole set of predictors, was rather unsatisfactory and we excluded variables that showed no significant influence on the RMI and that were correlated with other variables. We accepted the more parsimonious model if the model diagnostics were improved, thus minimizing the AIC-value and maximize the $\mathrm{r}^{2}$-value in the manual variable selection process.

\section{Results}

The results received during the two spring seasons were very consistent (Table 1) and the proportion of great reed warblers that was recaptured during days following ringing was $44.6 \%$ ( 25 out of 56 ringed) in 2015 and $51.2 \%$ (31 out of 60 ringed) in 2016. Out of the recaptured birds nine individuals $(36.0 \%)$ were recaptured more than once in 2015 and the same figure for 2016 was twelve individuals (38.7\%). In spite of the high within year recapture rates no bird ringed in 2015 was recaptured in 2016. Birds that were recaptured had in both years on average lower body mass when ringed than those that were only captured once (2015: $\mathrm{t}_{54}=3.37$, $\mathrm{p}=0.001$ and 2016: $\mathrm{t}_{58}=2.51, \mathrm{p}=0.014$, Fig. 2). However, at the last trapping occasion the average body mass in recaptured birds was not different from birds only trapped once (2015: $\mathrm{t}_{54}=0.38, \mathrm{p}=0.70$ and 2016: $\mathrm{t}_{58}=0.80$, $\mathrm{p}=0.42$, Table 1$)$. There was no difference in average minimum stopover time between years (Mann-Whitney $U$ test, $\mathrm{Z}=0.82, \mathrm{p}=0.42$, Table 1 ) and the longest minimum stopover time was $12 \mathrm{~d}$ in 2015 and $9 \mathrm{~d}$ in 2016. Average body mass increase during the stopover was very similar between years (Table 1) and in both years there were individuals that increased more than $10 \mathrm{~g}$ during their stay.
The average fuel deposition rate was not different between years $\left(t_{54}=0.80, p=0.43\right.$, Table 1$)$ and the average fuel deposition rate for pooled data was $1.1 \pm 0.7 \mathrm{~g} \mathrm{~d}^{-1}$. Birds recaptured the first day after ringing showed on average a slightly higher fuel deposition rate (2015: $1.3 \pm 0.5 \mathrm{~g} \mathrm{~d}^{-1}$, $\left.\mathrm{n}=11.2016: 1.2 \pm 0.96 \mathrm{~g} \mathrm{~d}^{-1}, \mathrm{n}=17\right)$ than average fuel deposition rate. Great reed warblers at Anapodaris increased in mass at an average relative rate of $4.8 \pm 2.9 \%$ of LBM $\mathrm{d}^{-1}$ and birds that were recaptured after one and two days showed a larger variation in RMI than birds that stayed longer time (Fig. 3). Fat score at ringing was strongly correlated with body mass (Pearson's correlation: $2015 \mathrm{r}=0.79$, $\mathrm{p}<0.001$ and $2016 \mathrm{r}=0.78, \mathrm{p}<0.001)$. The average fat score in recaptured birds increased from 2.3 at ringing to 4.0 at the last recapture while muscle score increased from 1.6 to 1.8 from ringing to the last recapture. The average body mass at ringing in birds with fat score zero was $23.2 \pm 1.3 \mathrm{~g}$ $(\mathrm{n}=11)$ and the average body mass in birds with fat score $5-6$ was $33.5 \pm 3.0 \mathrm{~g}(\mathrm{n}=18)$. Both wing length (Pearson's correlation: $2015 \mathrm{r}=-0.45, \mathrm{p}<0.001$ and $2016 \mathrm{r}=-0.46$, $\mathrm{p}<0.001)$ and body mass at ringing decreased over time of season (Pearson's correlation: $2015 \mathrm{r}=-0.58, \mathrm{p}<0.001$ and $2016 \mathrm{r}=-0.49, \mathrm{p}<0.001)$. The same was true for fat score (Pearson's correlation: $2015 \mathrm{r}=-0.50, \mathrm{p}<0.001$ and 2016 $\mathrm{r}=-0.28, \mathrm{p}=0.03)$, indicating that birds ringed later in the season were smaller and had less energy stores when ringed.

The linear model shows that hour of ringing and minimum stopover time both have a significant negative effect on RMI, while wing length and body mass increase both have a significant positive effect on the RMI (Table 2). Thus, the later in the day a bird is ringed and the longer it is present at the site, the lower was the rate of body mass gain. Furthermore, the longer the wing of the bird, the faster it increases in body mass and the larger the total increases in body mass, the faster the increase is. We found no significant effects on relative mass increase of body mass at ringing, day of ringing, hour of recapture, year and fuel load, which were successively excluded during the model selection process.

\section{Discussion}

The precipitation during the preceding winter on Crete varied very much between the two study years. In the village of Mesochorio (about $12 \mathrm{~km}$ from Anapodaris river mouth) the amount of rain measured during December-March in 

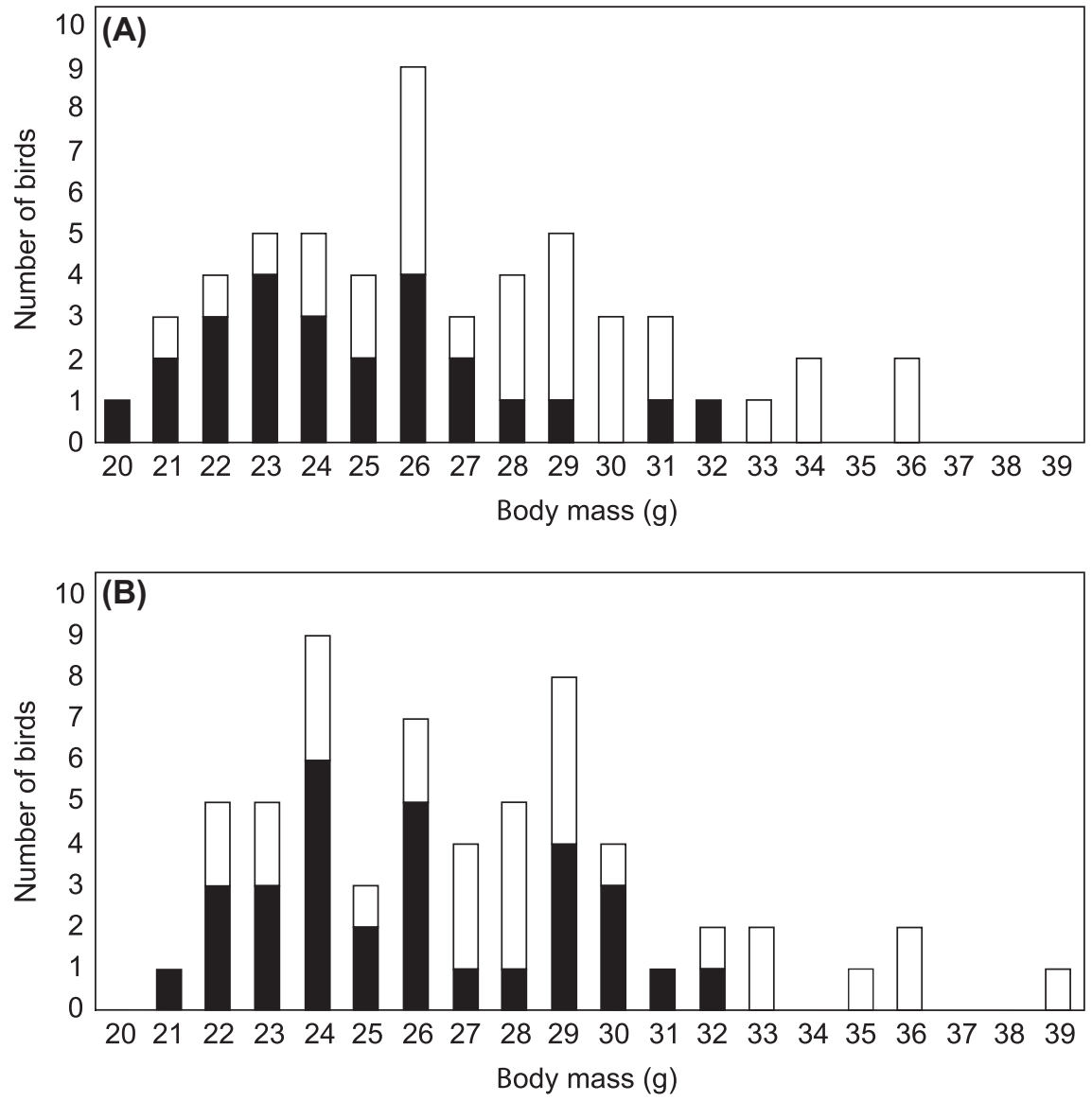

Figure 2. Body mass distribution of ringed great reed warblers at Anapodaris river mouth in (A) 2015 and (B) 2016. Black bars represent birds that were recaptured at least once after ringing while white bars represent birds that were not recaptured.

2014/2015 was $542 \mathrm{~mm}$ while only $149 \mathrm{~mm}$ was registered during the same period in 2015/2016 (M. Kozirakis pers. comm.). The greenery at the study site as well as everywhere on southern Crete differed greatly between the two years and it might have been expected that this should have an effect on stopover behaviour in migrant birds passing Crete. In spite of this difference the stopover behaviour in great reed warblers was very similar in the two spring seasons.

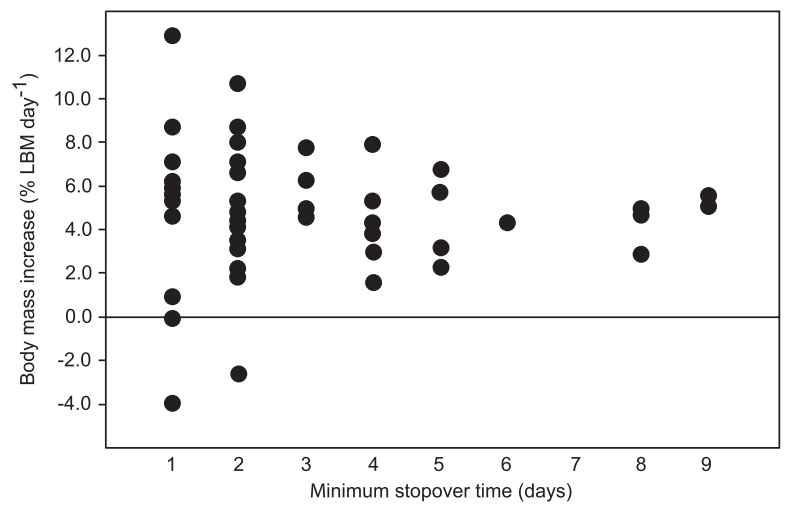

Figure 3. Rate of body mass increase ( $\%$ of lean body mass $\mathrm{d}^{-1}$ ) in relation to number of days between ringing and last recapture in great reed warblers $(n=55)$ at Anapodaris river mouth, southern Crete, in spring 2015 and 2016.
The recapture rates of around 50\% found in this study are exceptionally high compared to what is normally found at ringing sites for migratory birds, i.e. 2-20\% (cf. Salewski and Schaub 2007, Schaub et al. 2008, Chernetsov 2011, Gargallo et al. 2011). Information from the western part of the Mediterranean shows recapture rates of great reed warblers at ringing sites in Morocco and Spain varying between 2.7 and 15.6\% (Gargallo et al. 2011). At Antikythira, NW of Crete (Fig. 1), a slightly higher recapture rate, $22.8 \%$, of ringed great reed warblers was found during 2011-2016 (Antikythira Bird Observatory pers. comm.), but this is still much lower than in this study. Many places around the world where ringing of migrants is carried out are situated on small islands or at coastal sites where birds are concentrated after

Table 2. Results from a linear model showing predictors found to have a significant effect on RMI (relative body mass increase $d^{-1}$ ) in great reed warblers at Anapodaris river mouth, Crete, in 2015 and $2016\left(r^{2}=0.93\right.$, F-statistic $=170.5$ on 4 and 51 degrees of freedom $)$. The following predictors were excluded from the final model: body mass at ringing, day of ringing, hour of recapture, year and fuel load.

\begin{tabular}{lcc}
\hline Predictor & Coefficient estimate & p-value \\
\hline Hour of ringing & -0.0039 & 0.0044 \\
Wing length & 0.0010 & $<0.0001$ \\
Minimum stopover time & -0.0161 & $<0.0001$ \\
Body mass increase & 0.0152 & $<0.0001$ \\
\hline
\end{tabular}


completing a flight stage and easily trapped, but those sites are often not ideal for fuelling. It has, however, been shown in several studies that migrants are able to locate habitats that fulfil their species specific requirements, although it is unclear exactly how they manage to do it (cf. Moore and Aborn 2000, Ktitorov et al. 2008, Chernetsov 2011, Stach et al. 2014). In spite of that this study took place in the peak of spring migration, relatively low numbers of migrants were ringed at Anapodaris river mouth and great reed warblers comprised 26.4 and $24.3 \%$ of all migrants ringed in 2015 and 2016, respectively. The equivalent figure for Antikythira during the same period was 2.6\% (28 out of 1098 birds ringed) in 2015 and $1.0 \%$ (23 out of 2199 bird ringed) in 2016 (Antikythira Bird Observatory pers. comm.). This indicates that the reed beds at the river mouth at Anapodaris is a habitat preferred by great reed warblers that they actively seek out as a suitable refuelling site. Birds with shorter wing length arrived later and this is also found in western Mediterranean (Gargallo et al. 2011). Males are larger than females (Cramp 1992) and the pattern found strongly suggests that males have a slightly earlier passage than females, which is a pattern that has been found also at the arrival to the breeding sites (male great reed warblers arrive on average $11 \mathrm{~d}$ earlier than the females in south central Sweden; Tarka et al. 2015), as well as in other Acrocephalus species (Saino et al. 2010).

The RMI was affected by hour of ringing, minimum stopover time, wing length and body mass increase, and the model explained a large part of the variation in RMI $\left(r^{2}=0.93\right.$, Table 2$)$. The negative effect of hour of trapping is most likely an effect of the birds generally being heavier later in the day when they have consumed food, as opposed to birds ringed in the morning, reducing the apparent RMI. The minimum stopover time is probably linked to the RMI in that birds increasing in body mass slower also remain longer at the site. The positive effect of wing length and body mass increase are both probably related to the difference in size between the sexes of the great reed warbler, indicating that males have a larger RMI than females and hence probably a higher migration speed. Also, it can be noted that several of the excluded predictors to some extent contains the same information as the predictors remaining in the model. For example is day of ringing significantly negatively correlated with wing length. We could have excluded wing length instead of day of ringing, but since the effect of wing length we see on RMI probably is due to differences between the sexes, we want the variable giving the clearest indication of the sex of an individual, which arguably is wing length. Similar reasoning can be used as motivation of the exclusion of the, with wing length, significantly positively correlated predictor body mass at ringing. Also, the goodness of fit of the model increased when not excluding wing length, further indicating that it is the most informative of these correlated predictors to show the effect of sex on the RMI.

The body mass increase of $4.8 \%$ LBM d$^{-1}\left(1.1 \mathrm{~g} \mathrm{~d}^{-1}\right)$ observed in the great reed warblers at this study site is close to what has been found as the maximum fuel deposition rates for populations of passerines during migration (Lindström 2003). The great reed warbler is mainly feeding on invertebrates and the result indicates that the stopover site at Anapodaris is rich in this kind of food. In Morocco and in mainland Spain slightly lower fuel deposition rates have been reported in great reed warblers during spring migration, 0.30 and $0.70 \mathrm{~g} \mathrm{~d}^{-1}$, respectively (Gargallo et al. 2011). However, at some wetland sites in the Balearics slightly higher body mass gain have been found, although sample sizes were very small (Gargallo et al. 2011). It has been assumed that when birds arrive to a new stopover area it might take some days before they start gaining mass because of a period of search and settling (Alerstam and Lindström 1990). In several studies it has also been noted that birds lose body mass or show a lower body mass gain during the first days after ringing (cf. Ottosson et al. 2005, Arizaga et al. 2008). If this settling cost is mediated by ecological and/or physiological factors, or is an effect of handling, has been discussed (cf. Lindström 1995). It has been shown that birds change their physiology in connection with extended flights across barriers and it has been suggested that birds have to recover before being able to refuel for the continued migration (cf. Piersma and Lindström 1997, Gannes 2002, Bauchinger et al. 2005). However, in this study, recaptures one day after ringing show a slightly higher, rather than lower, fuel deposition rate than the average fuel deposition rate at this site. The stopover conditions at Anapodaris seem to be very good and it has been suggested that under such conditions birds might start gaining fuel without any delay (Chernetsov 2011). It is possible that birds while crossing the Sahara desert have been affected by dehydration (Klaassen 2004) and that a stopover site with available freshwater, like Anapodaris river mouth, makes it possible to quickly regain water balance. In concordance with this, birds that are provided water after the Sahara crossing has been shown to considerably increase their fuel deposition rate (Sapir et al. 2004).

The minimum stopover time of $3-4 \mathrm{~d}$ is similar to what has been found in great reed warblers in Morocco and Spain during spring migration (Gargallo et al. 2011). A problem when using recaptures to estimate stopover duration is that first and last capture may not represent the first and last day of the birds stay at the stopover. In addition to this, the probability of capturing a bird present in the area may not be equal throughout the duration of stopover. For example, if the migrant birds need to explore the area during the first days of stopover this may lead to a higher likelihood of capturing the bird early as compared to late during a stopover (Chernetsov and Mukhin 2006, Paxton et al. 2008). Thus, using data on first and last capture is likely to underestimate stopover duration (cf. Schaub et al. 2008, Chernetsov 2011) and in a study in west Africa the stopover duration was in eight species estimated to be $57 \%$ longer with a markrecapture analysis compared with minimum stopover estimates (Bayly et al. 2012). It is also worth mentioning that the calculated minimum stopover time refers to the birds that decide to make a stopover, while a proportion of birds are transients and only stay for one day before continuing migration. The high recapture rate found in this study indicates, however, that a large part of the great reed warblers that arrives at this site actually use the area for stopover and that some individuals regularly stay for $10 \mathrm{~d}$ or more. The fact that birds that were recaptured had clearly lower body mass when ringed than those that were not recaptured, suggests that birds with lower fuel loads use the site for refuelling while individuals with more fuel are more likely to continue their journey. In accordance, at the last recapture, recaptured 
birds had reached about the same average body mass as birds that were only captured once, and hence probably continued migration the following night.

The lowest recorded body mass was $20.8 \mathrm{~g}$ and the average body mass for birds that had no visible subcutaneous fat was $23.2 \mathrm{~g}$. Lemke et al. (2013) reports average body mass of male great reed warblers with no visible fat breeding in Sweden to be $33.9 \pm 2.4 \mathrm{~g}$, and Akriotis (1998) report slightly lower average values $(28-32 \mathrm{~g})$ for pre-migratory body masses of females and males in a Greek population. The extremely low body mass values found in this study may thus highlight the tremendous effort the desert crossing poses on the birds. During strenuous flights birds can utilize protein from muscular tissue and internal organs as flight energy, which causes severe reduction in size in these structures (Biebach 1998, Battley et al. 2000, Barboutis et al. 2011b). Since great reed warblers with visible substantial fat reserves (fat score 5 and 6) in our study, had similar average body mass as males without visible fat (fat score 0 ) recorded at breeding sites (Akriotis 1998, Lemke et al. 2013), our results suggests that birds did not completely rebuild structural tissue before increasing fuel loads. An alternative explanation would be that birds may differ in size between the studies (population and sex differences). This is, however, unlikely because the average size of the Anapodaris great reed warblers (97.1 $\mathrm{mm}$ ) was only slightly smaller than in Sweden $(98.3 \mathrm{~mm}$; average recalculated from data on average male $=100.4 \mathrm{~mm}$ and average female $=96.2 \mathrm{~mm}$ wing lengths of the Swedish population; Tarka et al. 2014) and the birds from Crete with the highest fat reserves (5-6) had an average body mass of $33.5 \mathrm{~g}$, which is even somewhat below the average of $33.9 \mathrm{~g}$ for great reed warblers without visible fat $(0)$ at a breeding site in Sweden (Lemke et al. 2013). Moreover, there was a $10.3 \mathrm{~g}$ difference in average body mass between birds without visible fat (i.e. fat score 0 ) and birds with high fat reserves (i.e. fat score 5-6) at Anapodaris showing that a great part of the body mass increase is due to fat accumulation. Thus, this substantial differences in body mass between lean birds in Sweden during breeding and fat birds stopping over at Anapodaris after the Sahara crossing in spring cannot be explained only by population (size) difference or developmental stage of the gonads (Bauchinger et al. 2007). Instead, the substantially lower body mass (also in birds with high fat scores) is a strong indication that the great reed warblers staging at Anapodaris still had not been able to rebuild their structural tissue after the strenuous Sahara crossing. This also suggests that rebuilding structural tissue after a substantially long migratory journey may be more demanding and timeconsuming than previously thought, and that songbirds crossing migration barriers may not be able to regenerate structural tissue immediately after the long flight, but may have to do this at subsequent stopovers or even when arriving at the breeding site.

The south coast of Crete, where the study site is located, is the first land migrants reach in this area after crossing the Sahara and the Mediterranean Sea in spring (Fig 1). The distance from the study site to suitable foraging areas south of the Sahara at this time of the year has been estimated to be about $2800 \mathrm{~km}$ (Barboutis et al. 2011a). The large variation in body mass found in this study indicates that some birds might have refuelled in north Africa or at other places in southern Crete before arriving at the study site. Some birds might also have been present at the study site for some days before they were ringed, but in light of the high recapture rate it is unlikely that they would have been around for many days without being captured.

The faster spring migration compared with autumn migration shown in several species indicates that there is competition for early arrival at breeding sites in migratory birds (Kokko 1999), and this is clearly the case also in the great reed warbler (Hasselquist 1998, Tarka et al. 2015). It might thus be expected that birds should depart as soon as they have reached enough fuel stores to continue migration after the desert crossing, particularly since they have no major barriers ahead. The results from this study indicate, however, that they stay longer than needed for accumulating reserves for one continued flight stage to the north. Based on $1 \%$ body mass loss per hour of flight (Delingat et al. 2008) and a flight speed of $12 \mathrm{~m} \mathrm{~s}^{-1}$ (Alerstam et al. 2007) a great reed warbler with a body mass of $30 \mathrm{~g}$ can cover a distance of about $1100 \mathrm{~km}$ and thereby reaching northern Balkan. It is interesting that the results found at this stopover site not only show that males have an earlier passage but also seem to have a higher fuel deposition rate than females, a pattern that has been found also in other species and has been suggested to strengthen protrandry (Seewagen et al. 2013). One reason for birds to accumulate large fuel loads at this site could be that southern sites provide more food than sites further north, where the advancement of the spring season is later (Hedenström 2008). Another possible reason for attaining an 'overload' could be that it is an investment for the approaching breeding season (Sandberg and Moore 1996, Fransson and Jakobsson 1998), which also has been shown to contribute to increased reproductive performance in a migratory passerine (Smith and Moore 2003). After crossing another barrier, the Gulf of Mexico, it seems as if some species in spring only perform a limited fuelling before continuing to the north (Yong and Moore 1997).

The migration of great reed warblers breeding in Sweden has recently been studied by means of geolocators showing that they in spring, following the desert crossing, make a stopover in north Africa (Tunisia and Algeria) for 6 to $11 \mathrm{~d}$ (Lemke et al. 2013). The stopover sites found in north Africa are at the same latitude as Crete, and since the desert more or less reaches the Mediterranean in the east, stopover in southern Greece might be a strategy for great reed warblers following a more eastern route. Recent geolocator studies have also shown longer stopover periods in northwest Africa following the Sahara crossing in turtle doves Streptopelia turtur and northern wheatears Oenanthe oenanthe (Eraud et al. 2013, Arlt et al. 2015). The stopover periods found in northern wheatears were on average $18.5 \mathrm{~d}$, which the authors believe is longer than needed for refuelling, and they suggest that it might partly be a strategy of using areas with good foraging conditions at a time when conditions in the wintering areas have deteriorated (Arlt et al. 2015).

The results from our study show that great reed warblers following the crossing of an ecological barrier (i.e. Saharan desert) are able to find stopover sites with preferred habitat and that they can use such sites for extensive fuelling. On Crete alone there are 201 very small $(<2 \mathrm{ha})$ to average sized (1200 ha) known wetlands (WWF Greece 2014). In 
addition to this, there are numerous small to large wetlands along the Mediterranean coast, that judging from our study site, most probably are of high conservation value for the great read warbler, and for other migratory passerines as well. Furthermore, our results highlight the importance of carefully choosing the sites when planning stopover studies. It might be expected that stopover site fidelity between years exist at sites like this in the same way that has been found close to the Sahara desert crossing in autumn (Cantos and Tellería 1994, Barboutis et al. 2014) even if no recaptures between years were found in our study.

Acknowledgements - Birds were trapped and studied with permission from the Ministry of Environment in Greece and from the Hellenic Bird Ringing Centre. We would like to thank Dimitris Hatzidakis, Lina Jansson, Tuomo Kolehmainen and Thomas Wenninger who were involved in the fieldwork. Thanks to Christos Angelidis for help with the maps used in Fig. 1 and to Manolis Kozirakis for information about precipitation. Thanks also to Markos Mouratis and his family for accommodation and support in Tsoutsouros. This is contribution no. 18 from Antikythira Bird Observatory - Hellenic Ornithological Society.

\section{References}

Akriotis, T. 1998. Post-breeding migration of reed and great reed warblers breeding in southeast Greece. - Bird Study 45: 344-352.

Alerstam, T. and Lindström, A. 1990. Optimal bird migration: the relative importance of time, energy and safety. - In: Gwinner, E. (ed.), Bird migration: physiology and ecophysiology. Springer, pp. 331-351.

Alerstam, T., Rosén, M., Bäckman, J., Ericson, P. G. P. and Hellgren, O. 2007. Flight speeds among bird species: allometric and phylogenetic effects. - PLoS Biol. 5: e197.

Arizaga, J,. Barba, E. and Belda, E. J. 2008. Fuel management and stopover duration of blackcaps Sylvia atricapilla stopping over in northern Spain during autumn migration period. - Bird Study 55: 124-134.

Arizaga, J., Maggini, I., Hama, F., Crespo, A. and Gargallo, G. 2013. Site- and species-specific fuel load of European-Afrotropical passerines on arrival at three oases of southeast Morocco during spring migration. - Bird Study 60: 11-21.

Arlt, D., Olsson, P., Fox, J. W., Low, M. and Pärt, T. 2015. Prolonged stopover duration characterises migration strategy and constraints of a long-distance migrant songbird. - Anim. Migr. 2: $47-62$.

Bairlein, F. 1995. European-African songbird migration network. Manual of field work. - Wilhelmshaven.

Barboutis, C., Henshaw, I., Mylonas, M. and Fransson, T. 2011 a. Seasonal differences in energy requirements of garden warblers Sylvia borin migrating across the Sahara Desert. - Ibis 153: 746-754.

Barboutis, C., Mylonas, M. and Fransson, T. 2011b. Breast muscle variation before and after crossing large ecological barriers in a small migratory passerine (Sylvia borin, Boddaert 1783). - J. Biol. Res. Thessalon. 16: 159-165.

Barboutis, C., Henshaw, I., Kullberg, C., Nikolopoulou, S. and Fransson, T. 2014. Fuelling in front of the barrier - are there age based behavioral diff erences in garden warbler Sylvia borin. - PeerJ 2: e319.

Battley, P. F., Piersma, T., Dietz, M. W., Tang, S., Dekinga, A. and Hulsman, K. 2000. Empirical evidence for differential organ reductions during trans-oceanic bird flight. - Proc. R. Soc. B 267: 191-195.
Bauchinger, U., Wohlmann, A. and Biebach, H. 2005. Flexible remodeling of organ size during spring migration of the garden warbler (Sylvia borin). - Zoology 108: 97-106.

Bauchinger, U., Van't Hof, T. and Biebach, H. 2007. Testicular development during long-distance spring migration. - Horm. Behav. 51: 295-305.

Bayly, N. J., Atkinson, P. W. and Rumsey S. J. R. 2012. Fuelling for the Sahara crossing: variation in site use and the onset and rate of spring mass gain by 38 Palearctic migrants in the western Sahel. - J. Ornithol. 153: 931-945.

Biebach, H. 1998. Phenotypic organ flexibility in garden warblers Sylvia borin during long-distance migration. - J. Avian Biol. 29: 529-535.

Cantos, F. J. and Tellería, J. L. 1994. Stopover site fidelity of four migrant warblers in the Iberian Peninsula. - J. Avian Biol. 25: 131-134.

Chernetsov, N. 2011. Passerine migration: stopovers and flight. - Springer.

Chernetsov, N. and Mukhin, A. 2006. Spatial behavior of European robins during migratory stopovers: a telemetry study. - Wilson J. Ornithol. 118: 79-83.

Cramp, S. 1992. Handbook of the birds of Europe, the Middle East and north Africa. The birds of the western Palearctic. Vol. VI warblers. - Oxford Univ. Press.

Delingat, J., Bairlein, F. and Hedenström, A. 2008. Obligatory barrier crossing and adaptive fuel management in migratory birds: the case of the Atlantic crossing in northern wheatears (Oenanthe oenanthe). - Behav. Ecol. Sociobiol. 62: 1069-1078.

Eraud, C., Rivière, M., Lormée, H., Fox, J. W., Ducamp, J.-J. and Boutin, J.-M. 2013. Migration routes and staging areas of trans-Saharan turtle doves appraised from light-level geolocators. - PLoS One 8: e59396.

Finlayson, J. C. 1981. Seasonal distribution, weights and fat of passerine migrants at Gibraltar. - Ibis 123: 88-95.

Flint, P. R. and Stewart, P. F. 1983. The birds of Cyprus. B.O.U. check list no. 6. - British Ornithologists Union.

Fransson, T. 1995. Routes and speed of migration in north and west European populations of Sylvia warblers. - J. Avian Biol. 26: 39-48.

Fransson, T. and Jakobsson, S. 1998. Fat storage in male willow warblers in spring: do residents arrive lean or fat? - Auk 115: 759-763.

Fransson, T., Barboutis, C., Mellroth, R. and Akriotis, T. 2008. When and where to fuel before crossing the Sahara desert - extended stopover and migratory fuelling in first-year garden warblers Sylvia borin. - J. Avian Biol. 39: 133-138.

Fry, C. H., Ash, J. S. and Ferguson-Lees, I. J. 1970. Spring weights of some Palaearctic migrants at lake Chad. - Ibis 112: $58-82$.

Gannes, L. Z. 2002. Mass change pattern of blackcaps refuelling during spring migration: evidence for physiological limitations to food assimilation. - Condor 104: 231-239.

Gargallo, G., Barriocanal, C., Castany, J., Clarabuch, O., Escandell, R., López-Iborra, G., Rguibi-Idrissi, H., Robson, D. and Suárez, M. 2011. Spring migration in the western Mediterranean and NW Africa: the results of 16 years of the Piccole Isole project. - Monografies del Museu de Ciències Naturals 6, Barcelona, Spain.

Hahn, S., Bauer, S. and Liechti, F. 2009. The natural link between Europe and Africa - 2.1 billion birds on migration. - Oikos 118: 624-626.

Handrinos, G. and Akriotis, T. 1997. The birds of Greece. - Christopher Helm.

Hasselquist, D. 1998. Polygyny in the great reed warbler: a long term study of factors contributing to male fitness. - Ecology 79: $2376-2390$ 
Hedenström, A. 2008. Adaptations to migration in birds: behavioural strategies, morphology and scaling effects. - Phil. Trans. R. Soc. B 363: 287-299.

Jenni, L. and Jenni-Eiermann, S. 1998. Fuel supply and metabolic constraints in migrating birds. - J. Avian Biol. 29: 521-528.

Klaassen, M. 2004. May dehydration risk govern long-distance migratory behaviour? - J. Avian Biol. 35: 4-6.

Kokko, H. 1999. Competition for early arrival in migratory birds. - J. Anim. Ecol. 68: 940-950.

Ktitorov, P., Bairlein, F. and Dubinin, M. 2008. The importance of landscape context for songbirds on migration: body mass gain is related to habitat cover. - Landscape Ecol. 23: 169-179.

Lavee, D., Safriel, U. N. and Meilijson, I. 1991. For how long do trans-Saharan migrants stop over at an oasis? - Ornis Scand. 22: 33-44.

Lemke, H. W., Tarka, M., Klaassen, R. H. G., Åkesson, M., Bensch, S., Hasselquist, D. and Hansson, B. 2013. Annual cycle and migration strategies of a trans-Saharan migratory songbird: a geolocator study in the great reed warbler. - PLoS One 8: e79209.

Lindström, Å. 1995. Stopover ecology of migrating birds: some unsolved questions. - Isr. J. Zool. 41: 407-416.

Lindström, Å. 2003. Fuel deposition rates in migrating birds: causes, constraints and consequences. - In: Berthold, P., Gwinner, E. and Sonnenschein, E. (eds), Avian migration. Springer, pp. 307-320.

Moore, F. and Aborn, D. A. 2000. Mechanisms of en route habitat selection: how do migrants make habitat decisions during stopover? - Stud. Avian Biol. 20: 34-42.

Moreau, R. E. 1972. The Palaearctic-African bird migration systems. - Academic Press.

Newton, I. 2008. The migration ecology of birds. - Academic Press.

Nilsson, C., Klaassen, R. H. G. and Alerstam, T. 2013. Differences in speed and duration of bird migration between spring and autumn. - Am. Nat. 181: 837-845.

Ottosson, U., Waldenström, J., Hjort, C. and McGregor, R. 2005. Garden warbler Sylvia borin migration in sub-Saharan west Africa: phenology and body mass changes. - Ibis 147: 750-757.

Paxton, K. L., Van Riper, C. I. and O’Brien, C. 2008. Movements patterns and stopover ecology of Wilson's warblers during spring migration on the lower Colorado river in southwestern Arizona. - Condor 110: 672-681.

Pettersson, J. and Hasselquist, D. 1985. Fat deposition and migration capacity of robins Erithacus rubecula and goldcrests Regulus regulus at Ottenby, Sweden. - Ring. Migr. 6: 66-76.

Piersma, T. and Lindström, Å. 1997. Rapid reversible changes in organ size as a component of adaptive behavior. - Trends Ecol. Evol. 12: 134-138.

Saino, N., Rubolini, D., Serra, L., Caprioli, M., Morganti, M., Ambrosini, R. and Spina, F. 2010. Sex-related variation in migration phenology in relation to sexual dimorphism: a test of competing hypotheses for the evolution of protandry. - J. Evol. Biol. 23: 2054-2065.

Salewski, V. and Schaub, M. 2007. Stopover duration of Palearctic passerine migrants in the western Sahara - independent of fat stores? - Ibis 149: 223-236.
Sandberg, R. and Moore, F. R. 1996. Fat stores and arrival on the breeding grounds: reproductive consequences for passerine migrants. - Oikos 77: 577-581.

Sapir, N., Tsurim, I., Gal, B. and Abramsky, Z. 2004. The effect of water availability on fuel deposition of two staging Sylvia warblers. - J. Avian Biol. 35: 25-32.

Schaub, M., Jenni, L. and Bairlein, F. 2008. Fuel stores, fuel accumulation, and the decision to depart from a migration stopover site. - Behav. Ecol. 19: 657-666.

Schmaljohann, H., Liechti, F. and Bruderer, B. 2009. TransSahara migrants select flight altitudes to minimize energy costs rather than water loss. - Behav. Ecol. Sociobiol. 63: 1609-1619.

Seewagen, C. L., Guglielmo, C. G. and Morbey, Y. E. 2013. Stopover refueling rate underlies protandry and seasonal variation in migration timing of songbirds. - Behav. Ecol. 24: 634-642.

Smith, R. J. and Moore, F. R. 2003. Arrival fat and reproductive performance in a long-distance passerine migrant. - Oecologia 134: 325-331.

Spina, F., Massi, A., Montimaggiori, A. and Baccetti, N. 1993. Spring migration across central Mediterranean: general results from 'Progetto Piccole Isole'. - J. Ornithol. 140: 419-430.

Stach, R., Fransson, T., Jakobsson, S. and Kullberg, C. 2014. Wide ranging stopover movements and substantial fuelling in first year garden warblers at a northern stopover site. - J. Avian Biol. 46: 315-322.

Sundberg, R. 2002. Collinearity. - In: El-Shaarawi, A. H. and Piegorsch, W. W. (eds), Encyclopedia of environmetrics. Volume 1. John Wiley and Sons, pp. 365-366.

Svensson, L. 1992. Identification guide to European Passerines. - Stockholm.

Tarka, M., Åkesson, M., Hasselquist, D. and Hansson, B. 2014. Intralocus sexual conflict over wing length in a wild migratory bird. - Am. Nat. 183: 62-73.

Tarka, M., Hansson, B. and Hasselquist, D. 2015. Selection and evolutionary potential of spring arrival phenology in males and females of a migratory songbird. - J. Evol. Biol. 28: 1024-1038.

Tøttrup, A. P., Klaassen, R. H. G., Strandberg, R., Thorup, K., Willemoes Kristensen, M., Søgaard Jørgensen, P., Fox, J., Afanasyev, V., Rahbek, C. and Alerstam, T. 2012. The annual cycle of a trans-equatorial Eurasian-African passerine migrant: different spatio-temporal strategies for autumn and spring migration. - Proc. R. Soc. B 279: 1008-1016.

Waldenström, J., Ottosson, U. and Haas, F. 2004. Morphometrical data from 30 bird species on spring migration in northern Tunisia. - Ornis Svecica 14: 129-133.

WWF Greece 2014. Conservation of the Island Wetlands of Greece (2004-2013): discovering the true value of Greek Island Wetlands. - WWF Greece.

Yong, W. and Moore, F. R. 1997. Spring stopover of intercontinental migratory thrushes along the northern coast of the Gulf of Mexico. - Auk 114: 263-278.

Zwarts, L., Bijlsma, R. G., van der Kamp, J. and Wymenga, E. 2009. Living on the edge: wetlands and birds in a changing Sahel. - KNNV Publishing. 